\title{
Mensagem do Presidente da ABPol
}

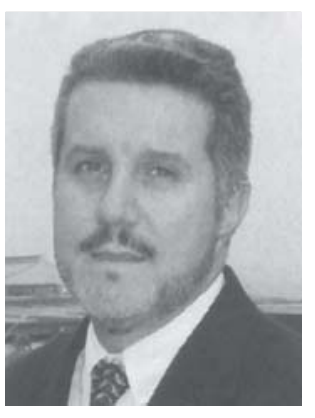

Como ocorre com as mais conhecidas marcas, o nome Brasilplast dispensa maiores apresentações. Mais que um nome, a Brasilplast é um fenômeno pois em seus 25 anos de existência a Feira cresceu, ganhou importância, se posicionou entre os 5 maiores eventos do negócio de polímeros no mundo e congrega hoje, em um só ponto de exposição, todos os setores ligados à ciência e tecnologia dos plásticos e borrachas incluindo matérias-primas, aditivos e equipamentos de teste e transformação de resinas e elastômeros. A presença institucional da ABPol na Feira Internacional de Plásticos do Brasil - Brasilplast 2005 garante a inserção da nossa Associação na chamada cadeia integrada dos negócios de polímeros e abre as portas para o contato interativo com todas as empresas, instituições, universidades, outras associações e profissionais atuantes na área e que convergem durante os 5 dias para o mesmo espaço ocupado pela Feira. Nossa participação, enfim, contribui para a ABPol cumprir sua missão de permear o conhecimento científico sobre os polímeros pelas diversas camadas da sociedade brasileira, permite a sempre desejável atualização das informações, promove o intercâmbio dos dados entre a academia, as instituições de pesquisa e as corporações industriais do setor plástico e alavanca a visibilidade da ABPol na comunidade dos polímeros. Como disse Dílson Funaro, então Presidente da Abiplast, na abertura de uma das primeiras versões da Feira (a Brasilplast) “...é um farol, que mostra as direções, define as tendências e ilumina os caminhos do setor plástico do Brasil". A ABPol está honrada em poder participar da Feira e pronta para dar a sua contribuição para o sucesso da Brasilplast 2005.

Domingos Jafelice

\section{EDITORIAL}

Como tem acontecido desde o início da publicação da revista, em anos ímpares, a edição janeiro/março de "Polímeros:Ciência e Tecnologia" é produzida com uma tiragem maior para distribuição durante a Brasilplast, uma das maiores feiras do plástico do mundo. Este ano, além da distribuição nesta Feira, a revista estará sendo distribuída também aos participantes do XInternational Macromolecular Colloquium (Gramado, 10-13 de abril) e do ISE 2005 $10^{\text {th }}$ International Seminars on Elastomers (Rio de Janeiro, 5-8 de abril). A participação de nossa revista nestes eventos caracteriza o objetivo maior da ABPol, como elemento de ligação entre o setor industrial e a academia. Esta aproximação permite ao profissional da indústria conhecer as pesquisas desenvolvidas nas universidades e institutos de pesquisa, ao mesmo tempo em que oferece ao pesquisador a oportunidade de observar novos produtos, equipamentos e processos e, não menos importante, estabelecer novos contatos e descobrir novas oportunidades de pesquisa.

No final de 2005 a ABPol estará realizando a $8^{\text {a }}$ edição do Congresso Brasileiro de Polímeros, mais uma oportunidade para que a comunidade científica e industrial possa expor seus trabalhos e trocar experiências. 